\title{
Cloudman S91 Malignant Melanoma
}

National Cancer Institute

\section{Source}

National Cancer Institute. Cloudman 591 Malignant Melanoma. NCI Thesaurus. Code C16444.

A transplantable melanoma that arose spontaneously in a mouse of DBA strain, and which grows and metastasizes in mice of related strains. (dictionarybarn.com) 